\title{
A Pseudomonas associated with disease in cultured rabbitfish Siganus rivulatus in the Red Sea
}

\author{
M. O. Saeed*, M. M. Alamoudi, A. H. Al-Harbi \\ Faculty of Marine Science, King Abdulaziz University, PO Box 1540, Jeddah 21441, Saudi Arabia
}

\begin{abstract}
Experiments were carried out to study the cause of a disease outbreak among rabbitfish Siganus rivulatus in the Saudi Arabian mariculture facility in the Red Sea and to investigate means of protecting fish against the disease. The causal agent of the disease proved to be a bacterium that was identified as Pseudomonas putrefaciens. When the bacterium was injected into healthy fish, it resulted in high mortality and produced the same clinical signs as those observed during the disease outbreak. A bacterin prepared by formalin killing was used to vaccinate fish. Fish vaccinated once by intraperitoneal injection suffered $17 \%$ less mortality than control fish when challenged with the homologous bacterium. Fish vaccinated twice by the same method suffered $40 \%$ less mortality than control fish. Fish were also vaccinated by direct immersion in the bacterin but when these fish and their unvaccinated counterparts were challenged by dipping into a suspension of the homologous bacterium they did not show any clinical signs nor did any mortality occur The disease was thought to be stress-related.
\end{abstract}

\section{INTRODUCTION}

Rabbitfish Siganus rivulatus are indigenous to the Indo-Pacific and now occur in the Red Sea and Eastern Mediterranean, where they are sought by fishermen and anglers because they are readily accepted by consumers. They are herbivorous but grow well on a low protein diet (Popper \& Gunderman 1975) and tolerate culture conditions (Thibaiti et al. 1984). Because of these characteristics, the Saudi Arabian Ministry of Agriculture and Water Resources has selected rabbitfish for initiation of a mariculture program in the Red Sea.

During spring 1985 a disease outbreak occurred and resulted in a high mortality in the sea cages. Following the initial epizootic, cases of the disease have frequently being diagnosed, the fish manifesting welldefined clinical signs (mentioned below). Primary isolation from all diseased fish resulted in substantial growth of bacteria whereas no parasites were evident on any fish. Bacterial infection was therefore thought to account for the disease.

\footnotetext{
- To whom correspondence should be directed
}

This study was undertaken to identify the responsible bacterium and to investigate the possibility of immunizing fish against it.

\section{MATERIALS AND METHODS}

Fish serving as the source of the pathogen were obtained as diseased specimens from the mariculture facility. The chief clinical signs were discoloration, hemorrhagic necrosis on the body and mouth, frayed fins, and exophthalmia. All specimens were moribund and were extremely lethargic.

Bacterial isolates were obtained from liver, kidney, and spleen on Brain Heart Infusion Agar (BHI agar) containing $3 \%$ salt $(\mathrm{NaCl})$. Subcultures of the predominating bacterium were made on the same medium and were kept for further investigations. Maximum and minimum tolerance limits as well as optimum growth conditions for salinity, temperature, and $\mathrm{pH}$ were determined. Biochemical characteristics of the bacterium were determined at $35^{\circ} \mathrm{C}$ using API $20 \mathrm{E}$ according to the manufacturer's instructions (Analytical Profile Index 1983), as well as at $22^{\circ} \mathrm{C}$. All tests were also supplemented by standard tube and other 
tests including Gram stain and growth on McConkey agar.

To investigate: the ability of the bacterium to produce disease in healthy fish, a saline suspension of the organism, equivalent to McFarland no. 6 turbidity standard, was inoculated intraperitoneally into healthy fish $\left(1 \mathrm{ml} \mathrm{fish}{ }^{-1}\right)$. Control fish were injected with $1 \mathrm{ml}$ of sterile saline. Average weight of fish used was $50 \mathrm{~g}$ and all fish were held in fiberglass tanks supplied with continuous flowing seawater and aeration. Dead fish were removed, necropsies were aseptically performed, and bacteria were isolated from liver, kidney, and spleen on plates of salt-supplemented BHI agar. Bacterial identification was carried out as previously described.

To vaccinate fish, a bacterin was prepared by formalin-killing washed cells of the bacterium, harvested from BHI culture broth. The procedure of Saeed \& Plumb (1986) was used. The bacterin was freeze-dried until used.

Fish for the vaccine experiments were caught by fish traps in the Red Sea. Their average weight was $60 \mathrm{~g}$. Fish were acclimated to $600 \mathrm{l}$ fiberglass tanks supplied with continuous flowing, aerated seawater. The water had salinity $38 \%, \mathrm{pH} 8.2$, and temperature between 29 and $31^{\circ} \mathrm{C}$. Fish were fed a commercial sinking-type pelleted diet containing $30 \%$ protein.

Fish were vaccinated by intraperitoneal injection or by direct immersion in the bacterin. Fish were intraperitoneally injected with either a single dose of bacterin $(0.2 \mathrm{mg}$ dry weight in $1 \mathrm{ml}$ of $1 \%$ saline) or with 2 doses of the bacterin (booster injection). For single injection, 3 groups of 30 fish each were used. Twenty of each group received the bacterin while the other 10 fish of each group were used as controls. Control fish were given an intraperitoneal injection of $1 \mathrm{ml}$ of sterile $1 \%$ saline. For booster injection, 30 fish were used: 20 received the bacterin on Days 0 and 7 and 10 received saline on Days 0 and 7 .

Twelve $\mathrm{d}$ after the initial vaccination ( $5 \mathrm{~d}$ after the booster injection for fish vaccinated twice), samples of experimental and control fish were bled and their serum antibody titers were determined using formalinkilled cells of the bacterium.

Sixty fish were used in an experiment to assess the efficacy of vaccination by immersion. Forty fish were immersed in the bacterin while 20 fish (controls) were left unvaccinated. Fish were vaccinated by immersion for $5 \mathrm{~min}$ in a vaccine that contained $0.5 \mathrm{mg}$ bacterin ( $\mathrm{ml}$ seawater) ${ }^{-1}$. Vaccinated fish were then washed by dipping into clear seawater before returning them to the experimental tank. Unvaccinated controls were immersed for 5 min into straight seawater. Fish were bled after $12 d$ and their antibody titers were determined as already described.
Fish vaccinated by injection were challenged $22 \mathrm{~d}$ after the initial vaccine injection by intraperitoneal injection of $1 \mathrm{ml}$ of saline containing $2.3 \times 10^{11}$ cells of the bacterium. Mortality of vaccinated fish was compared to that of the controls. Fish vaccinated by immersion were challenged by bath exposure. This was done by immersing both vaccinated and control fish in a suspension of the bacterium in seawater for $10 \mathrm{~min}$. The suspension contained $5.75 \times 10^{11}$ cells of the bacterium $\mathrm{ml}^{-1}$.

\section{RESULTS}

The bacterium grew at temperatures between 15 and $42^{\circ} \mathrm{C}$ and had an optimum grow th temperature of 30 to $37^{\circ} \mathrm{C}$. It grew over a relatively wide range of salinity $(0.85$ to $9.00 \% \mathrm{NaCl})$, with the optimum salinity for growth being between 1.0 and $3.0 \%$. Optimum $\mathrm{pH}$ was 8.9 but the bacterium tolerated $\mathrm{pH}$ values of 6.2 and 9.6 although it grew poorly and slowly at these $\mathrm{pH}$ extremes.

The bacterium was a Gram-negative rod and grew well on both Nutrient Agar and Brain Heart Infusion Agar media supplemented with salt. Biochemical characteristics are given in Table 1. Using the API $20 \mathrm{E}$ system, the bacterium was identified as Pseudomonas putrefaciens.

Healthy fish injected with a suspension of the bacterium all developed the clinical signs typical of the disease and showed $80 \%$ mortality within $48 \mathrm{~h}$. The injected bacterium was readily recovered from liver, kidney, and spleen of freshly dead fish.

Table 2 shows the humoral antibody response of the fish following vaccination by intraperitoneal injection and by immersion, and gives the mortalities that resulted following challenge with Pseudomonas putrefaciens.

\section{DISCUSSION}

In the biochemical tests, the bacterium was positive in all of those reactions in which $90 \%$ of known strains of Pseudomonas putrefaciens are positive. The identification of the bacterium as $P$. putrefaciens was therefore made with a high degree of confidence. The genus Pseudomonas is widely distributed in the sea because of its ability to use a variety of substances as food (Rheinheimer 1980). The species $P$. putrefaciens had been associated with fish disease in Singapore (Davy \& Graham 1978) and was isolated from haddock (Levin 1968, 1972), cod (Lee et al. 1977) and many fish in southeast Queensland, Australia (Gillespi 1981). It has been associated with hydrogen sulfide spoilage in 


\section{LITERATURE CITED}

Analytical Profile Index (API) (1983). Percentage of positive reactions in API plates. Leaflet on new instructions. Analytical Products, Plainview, New York, No. 1/83

Behairy, A. K., Abdulrahman, M. H. (1985). Effect of pollution on the coastal waters of the Red Sea in front of Jeddah. Saudi Arabia. 1. Environmental conditions. Collective Reprints. Faculty of Marine Science, King Abdulaziz University 1: 111-117

Davy, D., Graham, M. (1978). Workshop on disease of fish cultured for food in south east Asia. International Development Research Center, Ottawa

Gillespi, N. C. (1981). A numerical taxonomic study of Pseudomonas-like bacteria isolated from fish in southeastern Queensland and their association with spoilage. J Appl. Bacteriol. 50: 29-44

Hugh, R, Gilardi, G. (1974). Pseudomonas. In: Lennette, E. H. Spaulding, E. H., Traunt, J. P. (eds.) Manual of clinical microbiology. American Society for Microbiology, Washington, D.C., p. 250-269

Lee, J. V., Gibson, D. M., Shewan, J. M. (1977). A numerical taxonomic study of some Pseudomonas-like marine bacteria. J. gen. Microbiol. 98: 439-541
Levin, R. E. (1968). Detection and incidence of specific species of spoilage bacteria on fish. 1. Methodology. Appl. Microbiol. 16: 1734-1737

Levin, R. E. (1972). Correlation of DNA base composition and metabolism of Pseudomonas putrefaciens isolates from food, human clinical specimens and other sources. Antonie van Leeunhoek 38: 121-127

Popper, D., Gunderman, N. (1975). Some ecological and behavioural aspects of siganid populations in the Red Sea and Mediterranean coast of Israel in relation to their suitability for aquaculture. Aquaculture 6: 127-141

Rasheed, V. M., Plumb, J. A. (1984). Pathogenicity of a nonhaemolytic Group B Streptococcus sp. in Gulf killifish (Fundulus grandis). Aquaculture 37: 97-105

Rheinheimer, G. (1980). Aquatic microbiology. Cassel, London Saeed, M. O., Plumb, J. A. (1986). Immune response of channel catfish to lipopolysaccharide and whole cell Edwardsiella ictaluri vaccines. Dis. Aquat. Org. 2: 21-25

Thıbaiti, S. A., Bukhary, F. M., Bedawi, A. K. (1984). Culture of rabbitfish Siganus rivulatus in the Red Sea, Er-Rowda, Jeddah, Saudi Arabia (Arabic)

Walters, G. R., Plumb, J. A. (1980). Environmental stress and bacterial infection in channel catfish. J. Fish Biol. 17: $177-185$ 